\title{
Sorghum silage production system in Cariri, Paraíba
}

\section{Ebson Pereira Cândido', Edgard Cavalcanti Pimenta Filho², Severino Gonzaga Neto², Edson Mauro Santos², José Fábio Paulino de Moura ${ }^{3}$, Safira Valença Bispo²}

\footnotetext{
${ }^{1}$ Programa de Pós-Graduação em Zootecnia, Universidade Federal da Paraíba - Areia, PB, Brasil.

${ }^{2}$ Departamento de Zootecnia, Universidade Federal da Paraíba - Areia, PB, Brasil.

${ }^{3}$ Postdoctoral Fellow student of PRODOC/CAPES/UFPB - Areia, PB, Brasil.
}

\begin{abstract}
The objective of this study was to characterize the sorghum farming and ensiling systems in the Cariri region of Paraíba State (Brazil), and to identify different groups of producers based on productive characteristics using frequency distributions, and principal component and cluster analyses. A total of 100 milk producers in the Caturité and Boqueirão municipalities in the dairy region of Cariri, Paraíba, were selected to fill out a questionnaire comprised of 32 questions to collect data on both qualitative and quantitative variables. Of the 100 properties studied, $88 \%$ cultivated sorghum as silage forage for feeding dairy cows, demonstrating the importance of this cultural practice in the region of Cariri. Statistical analyses based on the variables studied identified four groups, composed of 35, 8, 6, and 39 farmers. The sorghum cultivation and ensiling production system in Cariri can be improved through the evaluation and improvement of soil fertility to obtain higher forage production, application of weed control using herbicides, and implementation of mechanized planting and harvesting to improve efficiency and reduce costs associated with manpower.
\end{abstract}

Key Words: principal components, semi-arid, Sorghum bicolor L. Moench

\section{Introduction}

Technology is one of the major factors in the management of a productive system. Based on the technology and methods utilized, it is possible to determine whether the maintenance of an efficient production system and the productive activity is sustainable, in both family and business contexts (Alexio et al., 2007). One technology adopted by milk producers in Cariri (microregion of Paraíba State, Brazil) is the cultivation of sorghum. Because of the wide acceptance of sorghum cultivation by farmers in this region as well as its regrowth capacity and lower demand for soil fertility compared with corn, it is one of the main sources of forage during periods of forage shortage in dairy herd feeding.

According to Machado et al. (2011), sorghum shows great flexibility and can be used in a variety of different forage production systems. It has a wide range of planting times, lower production costs, increased possibility for regrowth use, and because it is resistant to drought and high temperatures, it can be cultivated in regions unsuitable

Received August 20, 2012 and accepted February 28, 2014

Corresponding author: ebsonzoo@yahoo.com.br

http://dx.doi.org/10.1590/S1516-35982014000600008

Copyright (c) 2014 Sociedade Brasileira de Zootecnia. This is an Open Access article distributed under the terms of the Creative Commons Attribution Non-Commercial License, which permits unrestricted non-commercial use, distribution, and reproduction in any medium, provided the original work is properly cited. for corn growth. Neumann et al. (2008) noted that the relationship between production and forage quality is strictly dependent on the management conditions employed in cultivation, and dry matter production is the most important factor in determining the economic viability of forage. However, little information is available on the sorghum production system in Cariri, Paraíba. The Paraíba state has a large dairy industry, and has implemented Cooperativa Agropecuária do Cariri Ltda. (COAPECAL), which generates employment and income in this region. Therefore, it is important to identify the direct and indirect effects of management practices and their relationship with productivity.

Given the low productivity of dairy cattle in this region, it is essential to determine the major technologies employed in cultivation and ensiling of sorghum in order to enhance productivity to meet industry demands, increase revenues, ensure proper preservation of forage, and ensure the production of sorghum with a high nutritive value. Detailed knowledge of the technical, economic, and social systems of sorghum production in the Cariri region of Paraíba State is crucial for research planning, industry expansion, personnel training, and policy funding. Thus, the objective of this study was to characterize the sorghum production and ensiling systems in Cariri, Paraíba and to identify different groups of farmers based on the practices and technologies used in sorghum production. 


\section{Material and Methods}

Data were obtained from 100 milk producers that were randomly selected from farms in the dairy region that includes the Caturité and Boqueirão municipalities, both located in Cariri Region of Paraíba State, Brazil. The sample represented $24.45 \%$ of the total number of producers in the two municipalities (thus, the total universe consists of 409 producers). According to methods by Thompkin (1967) regarding the application of statistics in rural sociology, a satisfactory sample in a universe of 5,000 would be 50 individuals $+2 \%$. For this research, the sample consisted of 50 individuals $+12.22 \%$.

The two cities were analyzed together because both exhibit an aptitude for dairy cattle production, and there are similarities between the cities with respect to their soil and climatic characteristics as well as their approach to dairy herd management. The cities are also close in proximity, and cattle production is the main activity responsible for the socioeconomic development of this region.

The Caturité municipality has an area of $118.2 \mathrm{~km}^{2}$ and is located at $7.38^{\circ} \mathrm{S}$ latitude and a $36.06^{\circ} \mathrm{W}$ longitude. The study location is at an altitude of 405 meters and has a semiarid climate, with maximum and minimum temperatures of $37^{\circ} \mathrm{C}$ and $16{ }^{\circ} \mathrm{C}$, respectively, and an average precipitation of $500 \mathrm{~mm} /$ year (IBGE, 2006). The city of Boqueirão has an area of $424.65 \mathrm{~km}^{2}$ and is located $15 \mathrm{~km}$ away from the city of Caturité-PB. Boqueirão is located at $7.75^{\circ} \mathrm{S}$ latitude and $36.31^{\circ} \mathrm{W}$ longitude, and at an altitude of 520 meters. This city also has a semi-arid climate, with maximum and minimum temperatures of $40{ }^{\circ} \mathrm{C}$ and $19{ }^{\circ} \mathrm{C}$, respectively, and an average precipitation of $400 \mathrm{~mm} /$ year (IBGE, 2006).

For this study, a questionnaire comprising 21 qualitative and 11 quantitative questions was presented to each of the 100 properties to obtain information from these production units on their sorghum production and ensiling systems. The interviews were carried out from March to August 2011, following the Structured Interview method (Guilhermino, 2003), which is characterized by the presentation of planned questions to the respondent to obtain appropriate responses that meet the research objectives. The issues, answer options, and order of questions were identical for all respondents so as to ensure that variations in responses were due to individual differences rather than the interviewer differences.

Analysis of qualitative variables was performed by describing the frequency distribution, and principal components analysis (PCA) was used to examine similarities among the quantitative variables. The criterion for the number of discarded variables, as recommended by
Jolliffe (1973), was based on simulated and real data, and with the principal components from the correlation matrix. This criterion states that the number of variables discarded must be equal to the number of components whose variance (eigenvalue) is lower than 0.7. These analyses were performed using the PROC PRINCOMP procedure of the SAS software (Statistical Analysis System, version 9.3). After determining the number of principal components, scores for each principal component were estimated and clusters were identified using the TwoStep Cluster analysis procedure based on Euclidean distance. These analyses were performed using SPSS version 20.0 (SPSS Inc., Chicago, IL, USA).

\section{Results and Discussion}

The results of the questionnaire showed that of the 100 properties studied, $88 \%$ cultivated sorghum for silage, demonstrating that this practice was widespread in the region of Cariri (Table 1). Sorghum forage was the most commonly used $(98.86 \%)$ method of silage production employed by the surveyed properties. According to Morrill et al. (2012), sorghum is a rustic, fast-growing grass, and is widely used in various forms around the world. According to Cysne and Pitombeira (2012), sorghum has xerophilic characteristics, which include high tolerance of abiotic factors such as drought stress and salinity, and a low demand for mineral nutrients from the soil.

The sorghum planting season of the properties in Eastern Cariri commenced after the onset of the rainy season $(97.73 \%)$, without previous soil analysis (100\%). Thus, it was not possible to determine if the production

Table 1 - Qualitative variables for the technological aspects of production of sorghum silage in the municipalities of Caturité and Boqueirão in Cariri, Paraíba

\begin{tabular}{lc}
\hline Variables & \% occurrence \\
\hline Cultivation of sorghum for silage & \\
$\quad$ Yes & 88.00 \\
$\quad$ No & 12.00 \\
Use of forage for silage & \\
$\quad$ Sorghum & 98.86 \\
$\quad$ Corn & 1.14 \\
Soil analysis & \\
$\quad$ Yes & 0.00 \\
$\quad$ No & 100.00 \\
Fertilization & \\
$\quad$ Yes & 9.09 \\
$\quad$ No & 90.01 \\
Type of fertilization & \\
$\quad$ Organic & 75.00 \\
$\quad$ Chemical & 25.00 \\
Planting time & \\
$\quad$ Before rainy season & 2.27 \\
$\quad$ Beginning of rainy season & 97.73 \\
\hline
\end{tabular}


indices could have been improved by adjusting nutrient levels in the soils. Only $9.09 \%$ practiced soil fertilization, $75 \%$ of which was organic (Table 1), which demonstrates a lack of technical assistance regarding the benefits of soil analysis and correction so that the culture maintains itself in a sustainable manner over the years.

Only $10.23 \%$ of farmers owned tractors (Table 2) and $6.82 \%$ had planters, demonstrating the low level of modernization of dairy farmers in the region. However, producers need to calculate their annual usage in order to justify ownership as opposed to purchasing the services of a tractor and planter in the production of sorghum silage. In contrast, $97.73 \%$ of producers held soil tillage, and $87.50 \%$ used a tractor for this purpose, which demonstrates a high level of technology in this agricultural practice compared with milk producers from the rest of the state.

Soil tillage was accomplished by harrowing $(98.86 \%)$ and only $1.14 \%$ of the participants plow the soil, a practice which allows the bars to mobilize the soil surface layers, but does not promote windrow turning of the ridge with the same efficiency as harrowing (Bavoso et al., 2010). Plowing is also used to mitigate soil compaction, since the disk reaches deeper than the compacted layer (Drescher et al., 2011). In the case of light soils, harrowing is

Table 2 - Qualitative variables for the technologies used for planting sorghum in the municipalities of Caturité and Boqueirão in Cariri, Paraíba

\begin{tabular}{lc}
\hline Variables & \% occurrence \\
\hline Owns tractor & \\
Yes & 10.23 \\
No & 89.77 \\
Owns planter & \\
$\quad$ Yes & 6.82 \\
No & 93.18 \\
Soil tillage & \\
Yes & 97.73 \\
No & 2.27 \\
Land cutting & \\
Animal traction & 12.50 \\
Mechanical & 87.50 \\
Soil tillage type & \\
Plowing & 1.14 \\
Harrowing & 98.86 \\
Sowing & \\
Manual & 87.50 \\
Mechanical & 12.50 \\
Spacing between rows & \\
$50 \mathrm{~cm}$ & 10.23 \\
$70 \mathrm{~cm}$ & 13.64 \\
$80 \mathrm{~cm}$ & 50.00 \\
$90 \mathrm{~cm}$ & 26.13 \\
Amount of seeds/ha & \\
$15 \mathrm{~kg}$ & 10.23 \\
$20 \mathrm{~kg}$ & 22.73 \\
$25 \mathrm{~kg}$ & 26.14 \\
$30-40 \mathrm{~kg}$ & 40.90 \\
\hline
\end{tabular}

generally sufficient for soil tillage, and producers are therefore acting properly.

Although the practice of soil tillage was almost completely mechanized, $87.50 \%$ of sowing was done manually, making this work more expensive and less efficient. This practice also leads to higher levels of expenditure on seeds, and results in more seeds per hole, which impairs their development and in some cases requires thinning the culture. Evaluating the effect of soil tillage and sowing operation speed in the implementation of sorghum forage crop, Rodrigues et al. (2011) observed that sorghum has higher yields when sowed using a direct sowing system at a $5 \mathrm{~km} / \mathrm{h}$ speed.

According to Albuquerque et al. (2011a), determining the ideal seeding density and the best arrangement of plants in an area are among the most important practices for obtaining higher production of sorghum. The optimal arrangement of plants permits efficient exposure to solar radiation, soil nutrients, and water (Albuquerque et al., 2011b). During visits to the properties, we noted that the producers used high seeding rates, which may compromise the development of the crop.

Sorghum harvesting was performed manually in $70.45 \%$ of properties. Of the $29.55 \%$ that employed a mechanical harvest, $7.95 \%$ of the producers had a harvester coupled to the wagon (Table 3). According to Souza et al. (2001), there are clear advantages provided by mechanical harvesting, as this approach reduces the execution time of the harvest and is less labor-intensive.

The spacing between rows was 70 to $80 \mathrm{~cm}(63.64 \%)$, which was a widespread practice in the area. According to

Table 3 - Qualitative variables for the technological aspects of the management and harvesting of sorghum, and filling of silos in the municipalities of Caturité and Boqueirão in Cariri, Paraíba

\begin{tabular}{lc}
\hline Variables & \% occurrence \\
\hline Crop management & \\
$\quad$ Yes & 20.45 \\
$\quad$ No & 79.55 \\
Use of herbicide & 3.41 \\
$\quad$ Yes & 96.59 \\
$\quad$ No & \\
Harvesting time & 70.45 \\
$\quad$ Manual & 29.55 \\
$\quad$ Mechanized & \\
Harvester coupled to the wagon & 7.95 \\
$\quad$ Yes & 92.05 \\
$\quad$ No & \\
Type of packing & 3.41 \\
$\quad$ Manual & 96.59 \\
$\quad$ Mechanized & \\
Type of silage & 97.73 \\
Trench profile & 2.27 \\
Surface &
\end{tabular}


Flaresso et al. (2000), a spacing distance of 70 to $80 \mathrm{~cm}$ for the cultivation of sorghum is suitable for most harvesters used by farmers as well as for plantings involving combinations of crops. However, Neumann et al. (2008) examined the associative effects of spacing between each row in the crop $(30,50$, and $70 \mathrm{~cm})$ and the plant density $\left(300,000 ; 450,000\right.$; and 600,000 plants $\left.\mathrm{ha}^{-1}\right)$, and showed that forage yield increased linearly with increased row spacing, regardless of the population density of the crop. Furthermore, an increased yield of $103.9 \mathrm{~kg} \mathrm{DM} / \mathrm{ha}$ was observed for each increase of $10 \mathrm{~cm}$ in row spacing, and the best yield, stability, and quality of sorghum crop were obtained in cultivations that used a row spacing of $70 \mathrm{~cm}$. However, only $13.64 \%$ of the farms surveyed used this distance between rows (Table 2). Therefore, there is a need for intervention concerning this practice for $36.36 \%$ of the producers so as to enhance productivity rates and improve the logistics of harvesting sorghum for silage.

The amount of seeds used per hectare was very high, with $40.90 \%$ of producers using between 30 and $40 \mathrm{~kg}$ seeds/ha. Although the recommended amount is from 5 to $7 \mathrm{~kg}$, the rate of seed germination is low, resulting in excessive use of seeding. However, subsequent thinning to obtain the desired density of plants is not performed, since the need for additional manpower would increase the cost of sorghum production.

The degree of maturation of sorghum seeds at harvest affects their initial quality, and the seeds harvested before or after physiological maturity have a lower storage potential (Carvalho and Nakagawa, 2000). This is directly related to the development of the sorghum panicle. With respect to storage conditions, humidity and temperature are the most important factors affecting the maintenance of seed quality and viability of seeds (Souza et al., 2009).

According to Lopes et al. (2009), intraspecific competition among plants is usually caused by high plant densities associated with reduced spacing. This causes shading, thereby reducing solar radiation exposure to the crop canopy, and increasing competition for nutrients and water (for rain-fed crops). Only $20.45 \%$ of producers employ cultural practices for crop management (Table 3). According to Archangelo et al. (2002), the lack of management can result in slow plant development and renders the plant very susceptible to weed interference during the first 60 days after emergence, which can result in a large reduction in crop production.

The use of herbicides on sorghum crops for weed control was incipient (3.41\%). According to Pellegrini et al. (2010), the use of chemical methods of weed control (i.e., herbicides) reduces labor costs and can eliminate undesirable plants when properly applied.
Silage packing was carried out by mechanical compression in $96.59 \%$ of the properties. According to results obtained by Tavares et al. (2009), increasing the packing density of the mass inside the silage improves the fermentation process because it reduces $\mathrm{pH}$ levels and increases the concentration of ammonia nitrogen. However, if this packing is excessive, it may contribute to increase losses by effluent. Trench silage was the type most commonly used by producers $(97.73 \%)$, compared with surface silage $(2.27 \%)$, due to its low cost of construction and its facility in loading, unloading, and compaction.

Multivariate analysis was carried out using the following quantitative variables: age of producer, time in the cattle industry, total area of the property, area planted with sorghum, spacing between rows, number of tractors used in harvesting and silo closing, manpower employed in harvesting and silo closing, silo closing time, amount of silo on the property, volume of the silo, and time elapsed from closing to opening. In this analysis, the first three principal components explained $69.46 \%$ of the total variation (Table 4), demonstrating that the technique of PCA was sufficient to identify features responsible for defining the groups or production systems. This approach decreases the level of work involved in the characterization of multiple variables, and concurrently improves the accuracy of the analysis as well as makes the data less complex to analyze and interpret (Moura et al., 2010).

Among the 11 principal components analyzed, seven (63.64\%) had a variance lower than 0.7 (eigenvalue lower than 0.7 ), which comprised components five to 11 . Therefore, the seven variables with higher coefficients, in absolute value, from the last principal component were discarded (Table 5). Variables with high correlations with the last major component must be discarded, as they have a negligible contribution to the total variation (Barbosa et al., 2005).

Table 4 - Principal components (CP), eigenvalues $\left(\lambda_{\mathrm{i}}\right)$, and percentage of variance explained by components (\% VCP) of the sorghum silage production system characteristics in Cariri, Paraíba

\begin{tabular}{lccc}
\hline $\begin{array}{l}\text { Principal } \\
\text { component }\end{array}$ & $\lambda_{\mathrm{i}}$ & \% VCP & $\begin{array}{c}\text { \% VCP } \\
\text { (cumulative) }\end{array}$ \\
\hline CP1 & 3.308 & 34.62 & 34.62 \\
CP2 & 2.330 & 21.18 & 55.81 \\
CP3 & 1.501 & 13.65 & 69.46 \\
CP4 & 0.838 & 7.62 & 77.07 \\
CP5 & 0.691 & 6.29 & 83.36 \\
CP6 & 0.508 & 4.62 & 87.97 \\
CP7 & 0.487 & 4.43 & 92.40 \\
CP8 & 0.351 & 3.19 & 95.59 \\
CP9 & 0.260 & 2.37 & 97.96 \\
CP10 & 0.176 & 1.61 & 99.56 \\
CP11 & 0.048 & 0.44 & 100.00 \\
\hline
\end{tabular}


Table 5 - Results of weighing the coefficients of the eleven characteristics of the sorghum silage production systems in Cariri, Paraíba

\begin{tabular}{|c|c|c|c|c|c|c|c|}
\hline \multirow{2}{*}{ Characteristics } & \multicolumn{7}{|c|}{ Coefficients } \\
\hline & CP11 & CP10 & $\mathrm{CP} 9$ & $\mathrm{CP} 8$ & $\mathrm{CP} 7$ & CP6 & CP5 \\
\hline F01 & -0.702 & 0.068 & -0.005 & 0.019 & -0.160 & 0.061 & -0.089 \\
\hline F02 & 0.697 & -0.073 & 0.103 & 0.025 & -0.091 & 0.044 & -0.134 \\
\hline F03 & 0.054 & 0.300 & -0.536 & -0.191 & 0.392 & -0.404 & -0.108 \\
\hline F04 & -0.061 & -0.842 & -0.169 & 0.097 & 0.061 & -0.010 & 0.097 \\
\hline F05 & 0.014 & 0.002 & -0.120 & 0.308 & 0.319 & 0.214 & 0.660 \\
\hline F06 & 0.066 & 0.247 & -0.143 & 0.610 & -0.478 & -0.050 & 0.204 \\
\hline F07 & 0.033 & 0.223 & -0.134 & 0.400 & 0.100 & 0.041 & -0.202 \\
\hline F08 & 0.040 & 0.054 & 0.163 & -0.358 & -0.535 & -0.340 & 0.337 \\
\hline F09 & -0.023 & 0.201 & 0.546 & -0.078 & 0.395 & -0.105 & 0.395 \\
\hline F10 & -0.051 & 0.001 & 0.525 & 0.270 & 0.135 & 0.059 & -0.405 \\
\hline F11 & 0.057 & 0.191 & -0.144 & -0.343 & -0.090 & 0.806 & 0.032 \\
\hline
\end{tabular}

F01 - age of the producer; F02 - time in the cattle industry; F03 - total area of the property; F04 - area planted with sorghum; F05 - spacing between rows; F06 - number of tractors used in harvesting and silo closing; F07 - manpower employed in harvesting and silo closing; F08 - silo closing time; F09 - amount of silo on the property; F10 - volume of the silo; F11 - time elapsed from closing to opening.

In a study characterizing bovine milk production systems in Cariri, Barra de Santana, and Caturité, Moura et al. (2010) used the PCA technique and found that of a total of 14 characters, only five $(37.7 \%)$ were selected as the most important for determining the milk production system. The variables suggested for disposal in this study were as follows, in order of least to most important to explain the total variation: age of producer, area cultivated with sorghum, amount of silo on the property, number of tractors used in harvesting and silo closing, silo closing time, time elapsed from closing to opening the silo, and spacing (Table 5). Based on these results, the following variables are recommended for use in future analyses: time in the cattle industry, total area of the property, hand labor used in harvesting and silo closing, and volume of the silo.

The characteristics selected for disposal showed significant Pearson's Linear Correlation with at least one variable that had been selected, i.e., they were redundant (Table 6). Thus, each selected feature should be responsible for a unique type of information and their joint action should be complementary to the general description of the production system of sorghum silage in Cariri.

Moura et al. (2010) reported a high correlation (0.7740) between the age of producer and time in the livestock industry. A similar result was obtained in this study (0.9451; $\mathrm{P}<0.01$ ), which justifies the disposal of the age of producer descriptor. The variable area planted with sorghum was excluded because it showed high correlation with the variables total area of the property $(0.6956 ; \mathrm{P}<0.01)$, labor used for harvesting and silo closing $(0.2872 ; \mathrm{P}<0.01)$, and volume of the silo $(0.4890 ; \mathrm{P}<0.01)$. Therefore, when the area of the property is larger, the area under cultivation with sorghum is also larger. Consequently, it would be necessary to increase the amount of manpower used for harvesting and silo closing, and it would also be essential to increase the volume of the silo.

The variable spacing between the rows was excluded due to the correlation $(-0.2256 ; \mathrm{P}<0.05)$ with the total area of the property, which shows that when the total area of the property is larger, smaller row spacing is used. Additionally, the variables number of tractors used in harvesting and silo closing, silo closing time, amount of silo on the property, and time elapsed from closing to opening the silo were discarded, as they were highly correlated (0.3915, 0.3468, 0.4844, and 0.4829, respectively) with total area of the property. Thus, larger properties require more tractors for use in harvesting and silo closing, and also require greater silo closure time, larger quantity of silo on the property, and greater time elapsed from closing to opening the silo.

Similar results were obtained by Alves et al. (2003), who observed a dramatic decrease in the number of significant and highly significant correlations after discarding redundant variables. These results indicate that

Table 6 - Correlation coefficients between the selected (horizontal) and discarded (vertical) descriptors of the sorghum silage production systems in Cariri, Paraíba

\begin{tabular}{lcccc}
\hline \multirow{2}{*}{$\begin{array}{l}\text { Discarded } \\
\text { descriptors }\end{array}$} & \multicolumn{4}{c}{ Selected descriptors } \\
\cline { 2 - 5 } & F02 & F03 & F07 & F10 \\
\hline F01 & $0.9451^{* *}$ & 0.1684 & 0.1684 & -0.0291 \\
F04 & 0.0142 & $0.6956^{* *}$ & $0.2872^{* *}$ & $0.4890^{* *}$ \\
F05 & $0.2326^{*}$ & $-0.2256^{*}$ & 0.0643 & -0.0968 \\
F06 & -0.2038 & $0.3915^{* *}$ & -0.2074 & $0.2317 *$ \\
F08 & 0.0785 & $0.3468^{* *}$ & $0.4394 * *$ & $0.3954^{*}$ \\
F09 & 0.0210 & $0.4844^{* *}$ & 0.0448 & 0.1069 \\
F11 & -0.0822 & $0.4824^{* *}$ & 0.1728 & $0.4705^{* *}$ \\
\hline
\end{tabular}

$*$ and ** Significant at 0.05 and 0.01 , respectively (significance determined by Pearson's correlation coefficient).

F01 - age of the producer; F04 - area planted with sorghum; F05 - spacing between rows; F06 - number of tractors used in harvesting and silo closing; F08 - silo closing time; F09 - amount of silo on the property; F11 - time elapsed from closing to opening. 
Table 7 - Characteristics of producers of sorghum silage groups in Cariri, Paraíba

\begin{tabular}{lcccc}
\hline \multirow{2}{*}{ Variable } & \multicolumn{3}{c}{ Group } \\
\cline { 2 - 5 } & I & II & III & IV \\
\hline Number of properties & 35 & 8 & 39 \\
Time in the livestock activity (year) & $20 \pm 8.7$ & $38.1 \pm 17.4$ & $28 \pm 14.7$ & $41 \pm 12$ \\
Total area of the property (ha) & $42.5 \pm 29.3$ & $150 \pm 43.3$ & $167.7 \pm 58$ & $61.3 \pm 30.4$ \\
Labor force $($ No. of workers) & $11.1 \pm 4.3$ & $20 \pm 4.9$ & $10.5 \pm 7.4$ & $14 \pm 3.6$ \\
Silage volume $\left(\mathrm{m}^{3}\right)^{2}$ & $192 \pm 119$ & $619 \pm 243$ & $980 \pm 510$ & $224 \pm 112$ \\
\hline
\end{tabular}

Data expressed as mean \pm standard deviation.

${ }^{1}$ Labor force used in harvesting and silo closing.

${ }^{2}$ Considered the total volume of all the silos on the property.

the method of variable disposal efficiently identified and discarded redundant variables and that the deletion did not result in a significant loss of information.

To complement the results obtained through PCA, clustering analysis was performed using the TwoStep cluster method, based on Euclidean distance. The group analysis summarizes the internally homogeneous observations. The properties formed four groups based on scores from the first three principal components. Groups I, II, III, and IV were composed of $35,8,6$, and 39 producers, respectively. Properties within each group were similar to each other with respect to the parameters evaluated (Table 7).

Groups II and IV were distinguished from the others by the increased amount of time spent on the dairy industry, highlighting their experience. However, this also reflects the higher age of the producers, which implies greater difficulty in breaking the cultural aspects in their approach to production. Groups II and III have, on average, properties with larger areas (150 ha and $167.7 \mathrm{ha}$, respectively); however, these two groups represent a small proportion of the interviewed producers.

Although the variable area planted with sorghum was discarded in the PCA, it was used to establish the relationship between labor force/ha of sorghum at the harvest moment and silo closing as well as to estimate the productivity per hectare of sorghum for each group. For this analysis, a ton of silage was considered to occupy $2 \mathrm{~m}^{3}$ of silo. After determining the volume of the silos, it was possible to estimate the quantity of silage produced, which was then divided by the area planted with sorghum over that period. The mean area under cultivation with sorghum was $4.44,11.63,11.67$, and 5.54 ha for properties comprising Groups I, II, III, and IV, respectively.

With respect to the labor force employed in harvesting and silo closing, it appears that Group III, despite managing larger land areas, hire less labor force during the silage process. This reflects the purchasing power of this group, since $66.67 \%$ of the producers of this group have tractor and harvester coupled to the wagon, using $0.63 \mathrm{men} / \mathrm{ha}$ of sorghum in the process. Conversely, the Group II producers used a higher level of labor at harvest and silo closing. However, when we analyzed the relationship between labor force/area cultivated with sorghum, this group used $1.72 / \mathrm{men} /$ ha of sorghum while Groups I and IV used 2.50 and $2.53 / \mathrm{men} / \mathrm{ha}$, respectively. This discrepancy is probably explained by the contracting of services of tractors and agricultural implements by Group II producers in the process of ensiling.

The properties comprising Group III had the highest estimated yield of sorghum, about $29.40 \mathrm{t} /$ fresh matter (FM)/ha, compared with the others, which had 21.56, 26.62, and 20.25/FM/ha (Groups I, II, and IV, respectively). This is explained by their approach to planting, since the producers of Group III perform mechanical planting in $66.67 \%$ and mechanical harvesting in $100 \%$ of the properties. Mechanical planting provides the plants with an even spatial distribution inside of the row and between rows as well as a proper planting depth. Additionally, the mechanical harvesting likely reduced losses that may occur during transportation while optimizing the time required for filling the silo.

Our analyses also determined that farmers who own tractors had a greater yield per area (28.05 t/FM/ha). Furthermore, producers who carry out mechanized planting had an average yield of $26.94 \mathrm{t} / \mathrm{FM} / \mathrm{ha}$, compared with the average yield of $21.77 \mathrm{t} / \mathrm{FM} / \mathrm{ha}$ by the producers who perform manual planting.

\section{Conclusions}

The system of cultivation and ensiling of sorghum used by producers of the Eastern Cariri region of Paraíba can be improved through the evaluation of soil fertility, implementing weed control using herbicides, and conducting mechanized planting and harvesting, thus optimizing production and reducing labor costs.

The description of production systems showed that producers in Groups I and IV have smaller property areas and a lower amount of stored silage in addition to having lower yields per hectare of sorghum, which indicates 
significant problems in their approach to the cultivation of sorghum.

The smallest group, comprising only $6.82 \%$ of the producers, own larger areas, have lower labor costs associated with the ensiling process, and also have better productivity per hectare of sorghum. Therefore, the transfer of technology and its adoption by the smaller farms are essential for improving production systems based on sorghum silage.

Finally, the use of multivariate analysis in the study of sorghum system production in dairy cattle farms is effective for detecting groups, identifying specific problems, reducing costs associated with planning, and aiding in transfer of technology to farmers.

\section{Acknowledgments}

The authors thank BNB/Fundeci for financing this research study.

\section{References}

Albuquerque, C. J. B.; Pinho, R. G. V.; Rodrigues, J. A. S. and Brant, R. S. 2011a. Espaçamento entre fileiras e densidade de semeadura do sorgo forrageiro para a região norte de minas gerais. Ciência e Agrotecnologia 35:494-501.

Albuquerque, C. J. B.; Pinho, R. G. V.; Rodrigues, J. A. S.; Brant, R. S. and Mendes, M. C. 2011b. Espaçamento e densidade de semeadura para cultivares de sorgo granífero no semiárido. Bragantia 70:278-285.

Aleixo, S. S.; Souza, J. G. and Ferraudo, A. S. 2007. Técnicas de análise multivariada na determinação de grupos homogêneos de produtores de leite. Revista Brasileira de Zootecnia 36:2168-2175.

Alves, R. M.; Garcia, A. A. F.; Cruz, E. D. and Figueira, A. 2003. Seleção de descritores botânico-agronômicos para caracterização de germoplasma de cupuaçuzeiro. Pesquisa Agropecuária Brasileira 38:807-818.

Archangelo, E. R.; Silva, A. A.; Silva, J. B.; Karam, D. and Cardoso, A. A. 2002. Seletividade e eficácia de herbicidas aplicados em pósemergência na cultura do sorgo forrageiro. Revista Brasileira de Milho e Sorgo 1:107-115.

Barbosa, L.; Lopes, P. S.; Regazzi, A. J.; Guimarães, S. E. F. and Torres, R. A. 2005. Avaliação de características de carcaça de suínos utilizando-se a análise dos componentes principais. Revista Brasileira de Zootecnia 34:2209-2217.

Bavoso, M. A.; Giarola, N. F. B.; Tormena, C. A. and Pauletti, V. 2010. Preparo do solo em áreas de produção de grãos, silagem e pastejo: efeito na resistência tênsil e friabilidade de agregados. Revista Brasileira de Ciência do Solo 34:227-234.

Carvalho, N. M. and Nakagawa, J. 2000. Sementes: ciência, tecnologia e produção. 4th ed. FUNEP, Jaboticabal.

Cysne, J. R. B. and Pitombeira, J. B. 2012. Adaptabilidade e estabilidade de genótipos de sorgo granífero em diferentes ambientes do Estado do Ceará. Revista Ciência Agronômica 43:273-278.

Drescher, M. S.; Eltz, F. L. F.; Denardin, J. E. and Faganello, A. 2011. Persistência do efeito de intervenções mecânicas para a descompactação de solos sob plantio direto. Revista Brasileira de Ciência do Solo 35:1713-1722.

Flaresso, J. A.; Gross, C. D. and Almeida, E. X. 2000. Cultivares de milho (Zea mays L.) e sorgo (Sorghum bicolor (L.) Moench.) para ensilagem no Alto Vale do Itajaí, Santa Catarina. Revista Brasileira de Zootecnia 29:1608-1615.

Guilhermino, M. M. 2003. O uso da informação na tomada de decisão de manejo para bovinos leiteiros. Boletim Técnico, 45. Série Tecnologia Apta. Instituto de Zootecnia, Nova Odessa.

IBGE - Instituto Brasileiro de Geografia e Estatística. 2006. Censo agropecuário do Brasil. Available at: <http://www.ibge.gov.br> Accessed on: Nov. 11, 2011.

Jolliffe, I. T. 1973. Discarding variables in a principal component analysis. II. Real data. Applied Statistics 22:21-31.

Lopes, S. J.; Brum, B.; Storck, L.; Lúcio, A. D.; Silveira, T. R. and Toebe, M. 2009. Espaçamento entre plantas de sorgo granífero: produtividade de grãos e qualificação do modelo estatístico. Ciência Rural 39:649-656.

Machado, F. S.; Rodríguez, N. M.; Gonçalves, L. C.; Rodrigues, J. A. S.; Ribas, M. N.; Pôssas, F. P.; Guimarães Júnior, R.; Jayme, D. G. and Pereira, L. G. R. 2011. Consumo e digestibilidade aparente de silagens de sorgo em diferentes estádios de maturação. Arquivo Brasileiro de Medicina Veterinária e Zootecnia 63:1470-1478.

Morrill, W. B. B.; Rolim, M. M.; Bezerra Neto, E.; Pedrosa, E. M. R.; Oliveira, V. S. and Almeida, G. L. P. 2012. Produção e nutrientes minerais de milheto forrageiro e sorgo sudão adubado com soro de leite. Revista Brasileira de Engenharia Agrícola e Ambiental 16:182-188.

Moura, J. F. P.; Pimenta Filho, E. C.; Gonzaga Neto, S.; Menezes, M. P. C.; Leite, S. V. F. and Guilhermino, M. M. 2010. Caracterização dos sistemas de produção de leite bovino no Cariri paraibano. Acta Scientiarum. Animal Sciences 32:293-298.

Neumann, M.; Restle, J.; Nörnberg, J. L.; Oliboni, R.; Pellegrini, L. G.; Faria, M. V. and Oliveira, M. R. 2008. Efeito associativo do espaçamento entre linhas de plantio, densidade de plantas e idade sobre o desempenho vegetativo e qualitativo do sorgo forrageiro. Revista Brasileira de Milho e Sorgo 7:165-181.

Pellegrini, L. G.; Nabinger, C.; Neumann, M.; Carvalho, P. C. F. and Crancio, L. A. 2010. Produção de forragem e dinâmica de uma pastagem natural submetida a diferentes métodos de controle de espécies indesejáveis e à adubação. Revista Brasileira Zootecnia 39:2380-2388

Rodrigues, J. G. L.; Fernandes, J. C.; Nascimento, F. M.; Gamero, C. A. and Bicudo, S. J. 2011. Caracterização física do solo e desempenho operacional de máquinas agrícolas na implantação da cultura do sorgo forrageiro. Semina: Ciências Agrárias 32:1813-1824.

Souza, C. M. A.; Queiroz, D. M.; Cecon, P. R. and Mantovani, E. C. 2001. Avaliação de perdas em uma colhedora de fluxo axial para feijão. Revista Brasileira de Engenharia Agrícola e Ambiental 5:530-537.

Souza, G. F. M. V.; Santos, C. M.; Santana, D. G. and Sá Júnior, A. 2009. Armazenamento de sementes de sorgo submetidas a diferentes graus de umidade de colheita. Semina: Ciências Agrárias 30:745-752.

Tavares, V. B.; Pinto, J. C.; Evangelista, A. R.; Figueiredo, H. C. P.; Ávila, C. L. S. and Lima, R. F. 2009. Efeitos da compactação, da inclusão de aditivo absorvente e do emurchecimento na composição bromatológica de silagens de capim-tanzânia. Revista Brasileira de Zootecnia 38:40-49.

Thompkin, J. R. 1967. Estatística e método de pesquisa em Ciências Sociais Rurais. Escola Superior de Agricultura "Luiz de Queiroz", Piracicaba. 